\title{
Low-grade intracranial meningioma with bilateral pulmonary metastases incidentally detected postpartum: a case report and review of the literature
}

\author{
Parviz Mardani ${ }^{1}$, Arash Safarian², Anita Ashari ${ }^{3}$, Sarina Pourjafar ${ }^{3}$, Mohammad Hossein Anbardar $^{4}$, \\ Negar Azarpira ${ }^{{ }^{*}}$ D, Masoud Vafabin ${ }^{6}$ and Shahaboddin Yousefi ${ }^{7}$
}

\begin{abstract}
Introduction: Meningiomas are the most commonly encountered intracranial tumors, usually showing indolent behavior. Extra-axial spreading and distant metastases are seldom detected in these tumors, and lung metastasis from a low-grade meningioma is a rare event.

Case presentation: This case report aimed to present the clinical, imaging, and pathological features of a 37-year-old Caucasian pregnant woman with bilateral lung metastases incidentally detected during preoperative workup ahead of surgery for a primary intracranial meningioma. The possible metastatic routes and risk factors of dissemination to the pulmonary circulation were discussed as well.

Conclusion: Metastasis must be considered in patients with intracranial meningiomas accompanied by venous sinus invasion and extension through the calvarium. Thorough paraclinical investigations are suggested in such cases.
\end{abstract}

Keywords: Meningioma, Extra-axial metastasis, Lung, Pregnancy, Case report

\section{Background}

Meningiomas are extra-axial tumors that are derived from the meningothelial cells of the arachnoid membrane. They are the most common types of primary brain tumor, and females are affected more than males, with a 2:1 ratio. Ionizing radiation and genetic syndromes such as neurofibromatosis type 2 (NF2) have been considered as the risk factors for meningiomas.

Meningiomas are mainly slow-growing. However, they can be aggressive or may even undergo malignant transformation in a small proportion of cases [1, 2]. According to the 2016 classification of central nervous system

\footnotetext{
*Correspondence: negarazarpira@gmail.com

${ }^{5}$ Transplant Research Center, Shiraz University of Medical Sciences, Shiraz, Iran
}

Full list of author information is available at the end of the article tumors by the World Health Organization (WHO), meningiomas are classified into three grades; that is, I, II (atypical), and III (malignant). It has been reported that, in the course of the disease, $0.1-1 \%$ of all primary meningiomas develop metastases, with the lung being the most frequent site of distant metastatic spread [1-3]. The present study aims to report the case of a pregnant patient with bilateral metastatic pulmonary lesions incidentally detected ahead of resection of the primary brain meningioma.

\section{Case presentation}

A 37-year-old Caucasian female presented at 18 weeks of gestation with the complaint of a slow-growing scalp mass. She had no history of headaches, blurred vision, nausea, or vomiting. In her past medical history, she had original author(s) and the source, provide a link to the Creative Commons licence, and indicate if changes were made. The images or other third party material in this article are included in the article's Creative Commons licence, unless indicated otherwise in a credit line to the material. If material is not included in the article's Creative Commons licence and your intended use is not permitted by statutory regulation or exceeds the permitted use, you will need to obtain permission directly from the copyright holder. To view a copy of this licence, visit http://creativecommons.org/licenses/by/4.0/. The Creative Commons Public Domain Dedication waiver (http://creativeco mmons.org/publicdomain/zero/1.0/) applies to the data made available in this article, unless otherwise stated in a credit line to the data. 

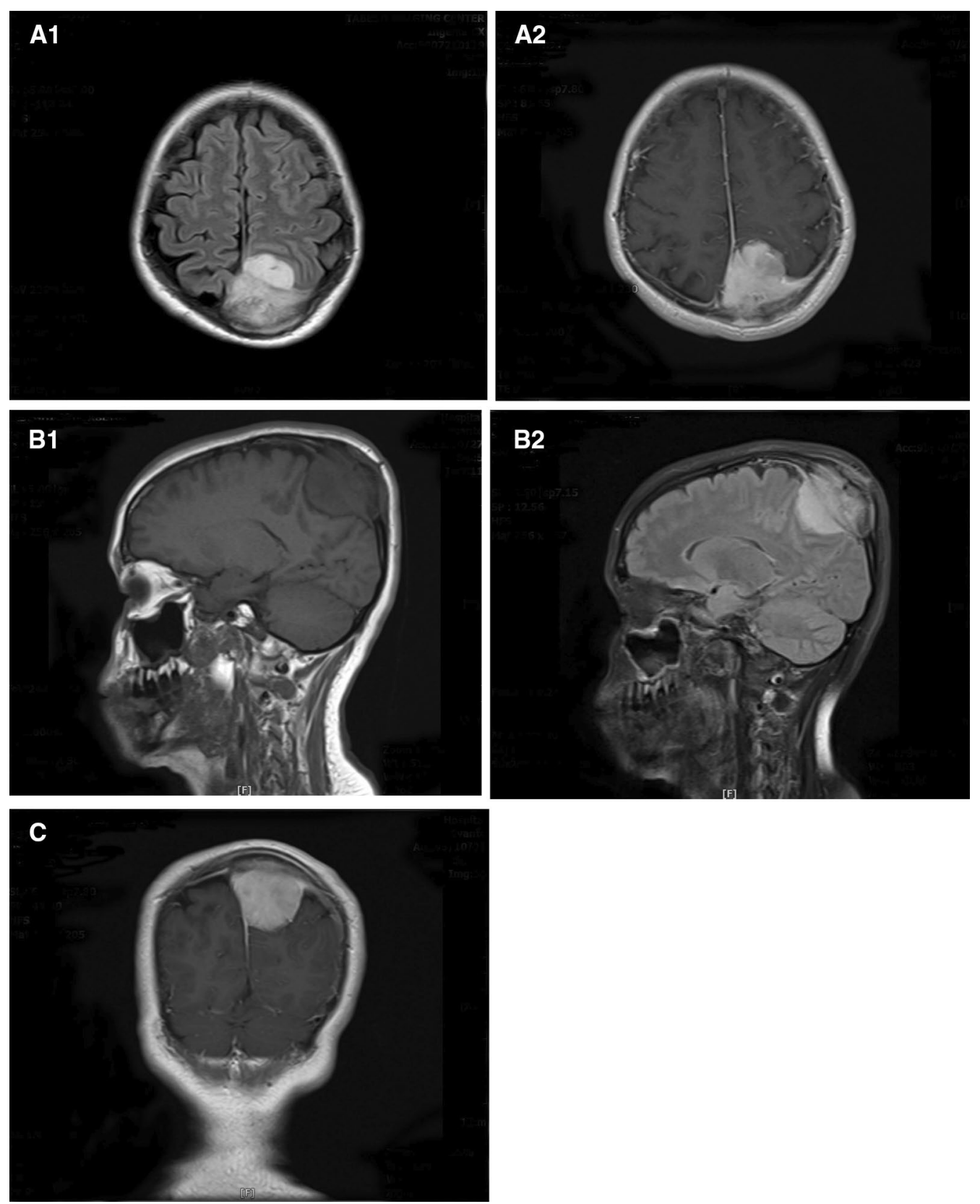

Fig. 1. Preoperative magnetic resonance imaging of the patient with intracranial meningioma, showing a homogeneously enhancing tumor in the parasagittal region: (A1, A2) axial, (B1, B2) sagittal, and (C) coronal views

two pregnancies with no complications. On palpation, a well-defined round-to-oval mass was detected with hard consistency. However, the physical examination was unremarkable. Her full-term baby was delivered via cesarean section without any fetal or maternal complications. One month postpartum, the patient was visited by a general surgeon and a tissue biopsy was obtained from the scalp mass. The pathology result was in favor of a grade I meningioma with skull bone involvement. Hence, the patient was referred to the neurosurgery ward. Therein, a brain magnetic resonance imaging (MRI) was done, and an extra-axial $39 \times 33 \times 25 \mathrm{~mm}$ mass isointense in T1, hyperintense in T2, was noted high in the parafalcine region of the left parietal lobe. The mass had a dural tail appearance. Adjacent hyperostosis and enhancement of the adjacent involved calvarium in the 


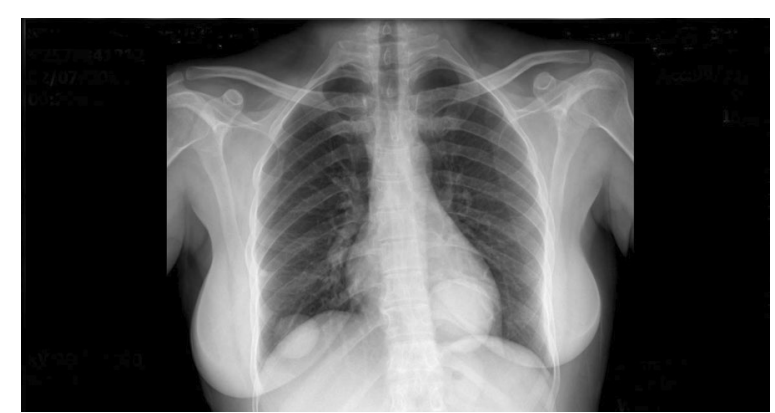

high parietal scalp were mentioned as well. The findings were suggestive of an intraosseous meningioma with both intra- and extracranial components (Fig. 1).

The patient's brain meningioma was operated in the neurosurgery department. Right frontoparietal craniotomy was performed, and the tumor was released from the brain tissue ahead of the gross total resection of the mass as well as the involved scalp. The postoperative pathology result of the brain mass was also in favor of Fig. 2. Chest $X$-ray showing bilateral intraparenchymal lung lesions grade I/III meningioma. The patient was discharged from
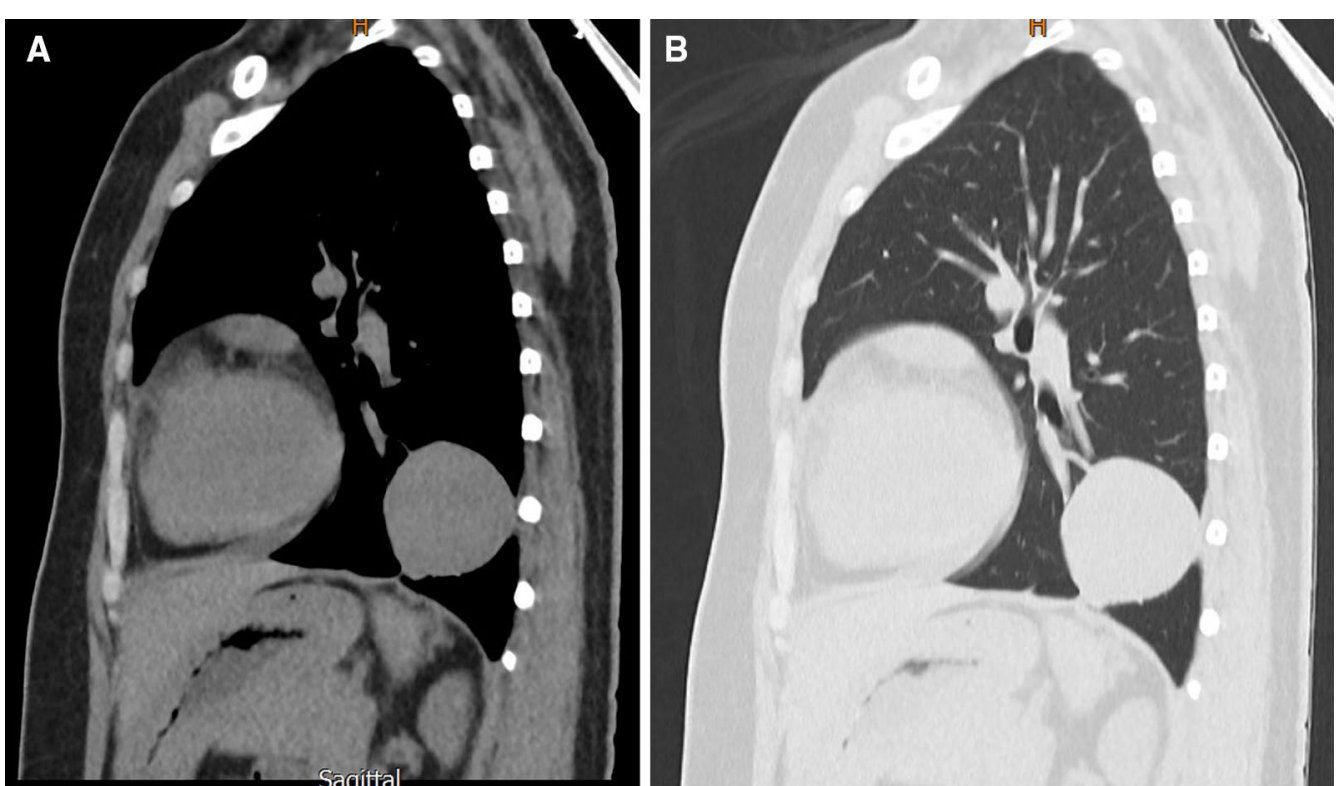

Fig. 3. Chest CT scan of the lung mass (lateral view). Two well-defined lung masses are apparent
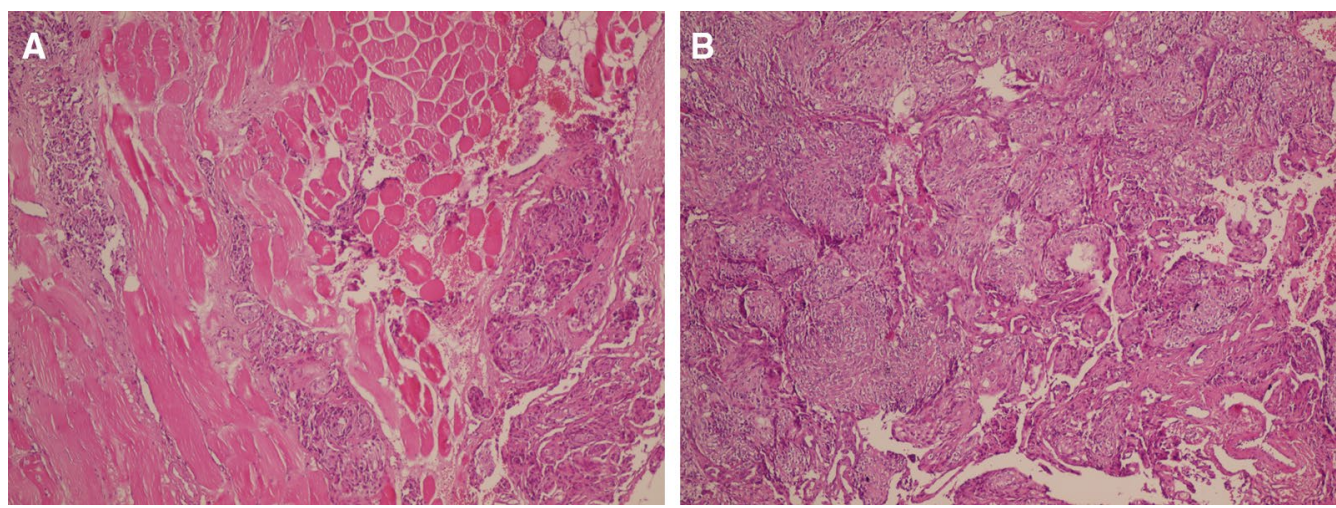

Fig. 4. Histopathology of the resected brain mass and the pulmonary lesion showing tumoral cells with whorled appearance without atypia and mitotic figures compatible with meningioma grade I (A). The same pattern is obvious in the lung (B) (hematoxylin and eosin $\times 100$ ) 

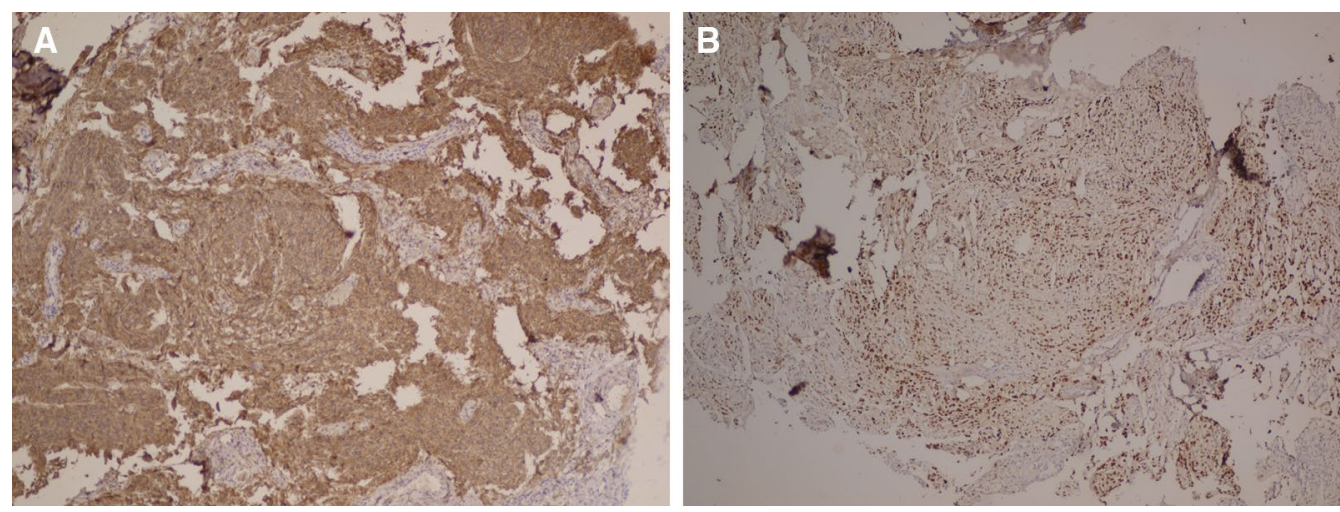

Fig. 5. Immunohistochemical staining showing tumor cells positive for epithelial membrane antigen $(\mathbf{A})$ and progesterone receptor $(\mathbf{B})(\times 100)$

the hospital with no complications and no adjuvant cranial radiotherapy.

During the preoperative workup ahead of brain surgery, bilateral lung masses were detected as an incidental finding on chest X-ray and high-resolution computed tomography (HRCT) scan (Figs. 2, 3). There was no history of cough, chest pain, hemoptysis, or difficulty breathing. Heart and lung physical examinations were unremarkable. Preoperative laboratory evaluation including routine complete blood tests, electrocardiogram, and spirometry were unremarkable as well.

A wedge resection of the left lobe lesion $(4 \times 5 \mathrm{~cm})$ was performed along with a Tru-Cut biopsy of a pleural-based mass in the right lower pulmonary lobe. The histological feature of the lung tumor was the same as that of the brain mass, and the diagnosis of metastatic meningioma was confirmed by immunohistochemistry (IHC). Accordingly, the tumor cells were positive for EMA, PR, and Ki67 (low) and negative for P63, TTF1, and chromogranin (Figs. 4, 5). Bilateral lesions were resected through staged thoracotomy with no postoperative complications. The patient did not require radiotherapy and chemotherapy. She was followed up via brain and chest CT scans after 2 months, revealing satisfactory residual respiratory function and no evidence of pulmonary relapse.

\section{Discussion}

Meningioma is a common primary slow-growing, intracranial, extra-axial neoplasm with attachment to the dura mater. It is composed of neoplastic meningothelial cells, and its usual growth rate is less than $1 \mathrm{~cm} /$ year, ranging from 0.03 to $2.62 \mathrm{~cm} /$ year [4]. Metastases may develop in less than $0.1 \%$ of patients, and lungs, liver, lymph nodes, and bones are the most common sites [5]. Pregnancy has been found to be associated with an increased incidence of symptomatic meningiomas in females, suggesting an increased tumor growth during this period [6]. On the other hand, attenuation of clinical symptoms and shrinkage of tumors have been reported during the postpartum period $[2,7]$.

Estrogen, progesterone, and prolactin levels are elevated during pregnancy, and the expression of the estrogen receptor (ER) and progesterone receptor (PR) has been found in a significant percentage of meningiomas [8]. These findings suggest that female sex hormoneinduced cell proliferation is the simplest explanation for the growth of meningioma during pregnancy. On the other hand, exogenous estrogen therapy has not been associated with an increased risk of meningioma, and no change has been detected in the tumor size during the follicular phase of menstruation when estrogen levels are highest $[8,9]$.

Lusis et al. conducted a study on the pathology specimen of meningiomas during pregnancy and disclosed that the frequency of PR positivity was similar to that of the control group [10]. Although PR expression was found in $70-95 \%$ of meningiomas, the same level of expression was observed in tumoral tissues of children and males with minimal progesterone levels $[10,11]$. Additionally, the grade of meningioma did not change during pregnancy [10].

Recently, Telugu et al. explored the expressions of ER and PR in meningioma specimens via IHC and assessed their correlations with gender, histological subtypes, and grade. The expression rates of ER and PR were $2 \%$ and $66 \%$, respectively. No significant correlation was detected between the positivity of PR and the above-mentioned variables [12]. Therefore, the levels of sex hormones and expressions of receptors in tumoral tissues alone cannot justify the growth of meningiomas during pregnancy.

Another hypothesis that prevails to date is that meningioma growth is associated with vascular changes during pregnancy such as intratumoral hypervascularity and tissue edema [10]. The exact mechanism of edema is 
Table 1. Demographic features, treatment and outcome of reported cases

\begin{tabular}{|c|c|c|c|c|c|c|}
\hline Reference & Age, years & Interval, years & Location & $\begin{array}{l}\text { Histology } \\
\text { WHO } \\
\text { grade }\end{array}$ & Treatment & Outcome \\
\hline Aumann et al. [13] & 45 & 5 & Left frontal parasagittal & । & Total resection & NA \\
\hline LeMay et al. [14] & 56 & 10 & NA & 1 & Partial resection & $\begin{array}{l}\text { Died of disease } 3 \text { years } \\
\text { after thoracotomy }\end{array}$ \\
\hline Hishima et al. [15] & 25 & $\begin{array}{l}\text { Prior to intracranial } \\
\text { tumor }\end{array}$ & $\begin{array}{l}\text { Right parietal region } \\
\text { adjacent to the falx }\end{array}$ & I & Partial resection & NA \\
\hline Murrah et al. [16] & 53 & 10 & $\begin{array}{l}\text { Left frontal hemi- } \\
\text { spheric convexity }\end{array}$ & NA & Partial resection & $\begin{array}{l}\text { Alive with disease } \\
2 \text { years after thora- } \\
\text { cotomy }\end{array}$ \\
\hline Adlakha et al. [17] & 39 & 6 & $\begin{array}{l}\text { Left parietal parasagit- } \\
\text { tal }\end{array}$ & $\|$ & $\begin{array}{l}\text { Partial resection and } \\
\text { gamma knife radio- } \\
\text { surgery }\end{array}$ & $\begin{array}{l}\text { Died of disease } 10 \text { years } \\
\text { after initial presentation }\end{array}$ \\
\hline Figueroa et al. [18] & 50 & 5 & Left cranial fossa & I & $\begin{array}{l}\text { Total resection and } \\
\text { radiotherapy for } \\
\text { metastases }\end{array}$ & $\begin{array}{l}\text { Alive with disease } \\
32 \text { years after radio- } \\
\text { therapy }\end{array}$ \\
\hline Travitzky et al. [19] & 41 & 19 & NA & III & $\begin{array}{l}\text { Total resection and } \\
\text { radiotherapy }\end{array}$ & $\begin{array}{l}\text { No evidence of disease } \\
6 \text { months after doxil- } \\
\text { induced regression of } \\
\text { metastases }\end{array}$ \\
\hline Erman et al. [7] & 34 & 8 & $\begin{array}{l}\text { Left frontal-parasag- } \\
\text { ittal }\end{array}$ & $\|$ & $\begin{array}{l}\text { Partial resection and } \\
\text { radiotherapy }\end{array}$ & $\begin{array}{l}\text { Died of disease shortly } \\
\text { after thoracotomy, } \\
\text { radiotherapy, and } \\
\text { chemotherapy of the } \\
\text { metastasis }\end{array}$ \\
\hline Psaras et al. [20] & 65 & 15 & $\begin{array}{l}\text { Falx cerebri and supe- } \\
\text { rior sagittal sinus }\end{array}$ & l & $\begin{array}{l}\text { Total resection and } \\
\text { radiotherapy }\end{array}$ & $\begin{array}{l}\text { No evidence of disease } \\
12 \text { months after thora- } \\
\text { cotomy }\end{array}$ \\
\hline \multirow[t]{3}{*}{ Alexandra et al. [21] } & 26 & NA & Multiple supratentorial & III & Partial resection & NA \\
\hline & 84 & NA & Right frontal & NA & Total resection & NA \\
\hline & 52 & NA & $\begin{array}{l}\text { Right frontal, left } \\
\text { parietal, and right } \\
\text { occipital }\end{array}$ & $\|$ & Partial resection & NA \\
\hline Sabet et al. [22] & 62 & Concurrent & Left frontal & III & $\begin{array}{l}\text { Partial resection and } \\
\text { radiotherapy }\end{array}$ & NA \\
\hline Nakayama et al. [23] & 25 & concurrent & Right parietal & 1 & Total resection & $\begin{array}{l}\text { No evidence of disease } \\
7 \text { years after last surgery }\end{array}$ \\
\hline Ocque et al. [24] & 44 & NA & NA & III & NA & NA \\
\hline $\begin{array}{l}\text { Frydrychowicz et al. } \\
\text { [25] }\end{array}$ & 45 & 5 & Left frontal & $\|$ & $\begin{array}{l}\text { Surgery and radio- } \\
\text { therapy }\end{array}$ & NA \\
\hline \multirow[t]{3}{*}{ Dalle Ore et al. [26] } & 69 & 5.4 & Cerebellum & III & No intervention & Alive after 5 months F/U \\
\hline & 75 & 9.2 & Falx, parasagittal & $\|$ & No intervention & $\begin{array}{l}\text { Alive after } 1.5 \text { months } \\
\text { F/U }\end{array}$ \\
\hline & 64 & 10.8 & Parasagittal & III & Hydroxyurea, EBRT & $\begin{array}{l}\text { Alive after } 13 \text { months } \\
\text { F/U }\end{array}$ \\
\hline Vakil et al. [1] & 91 & 1 & Left frontoparietal & III & $\begin{array}{l}\text { Radiotherapy with } \\
\text { sunitinib }\end{array}$ & $\begin{array}{l}\text { Alive after } 13 \text { months } \\
\text { F/U }\end{array}$ \\
\hline $\begin{array}{l}\text { Sathirareuangchai } \\
\text { et al. [27] }\end{array}$ & 59 & Concurrent & Left occipital convexity & I & Surgery & NA \\
\hline Wang et al. [2] & 54 & & Left middle cranial & 1 & Surgery & NA \\
\hline Som et al. [38] & 53 & 5 & Right sphenoid wing & 1 & Surgery & NA \\
\hline Kodama et al. [33] & 61 & 19 & Cerebellar & 1 & Surgery & NA \\
\hline Tao et al. [40] & 32 & 18 & Right frontal & I & Surgery & NA \\
\hline Shin et al. [37] & 53 & 9 & Left frontal & 1 & Surgery & NA \\
\hline Tworek et al. [41] & 50 & 6 & Left frontal & l & Surgery & NA \\
\hline Baisden et al. [29] & 71 & 13 & $\begin{array}{l}\text { Right middle cranial } \\
\text { fossa }\end{array}$ & $\|$ & Surgery & NA \\
\hline
\end{tabular}


Table 1. (continued)

\begin{tabular}{|c|c|c|c|c|c|c|}
\hline Reference & Age, years & Interval, years & Location & $\begin{array}{l}\text { Histology } \\
\text { WHO } \\
\text { grade }\end{array}$ & Treatment & Outcome \\
\hline Kovoor et al. [34] & 40 & 2 & Left parietal & । & Surgery & NA \\
\hline Pramesh et al. [36] & 29 & 9 & Right occipital & । & Surgery & NA \\
\hline Fabi et al. [31] & 57 & 1 & Right frontal & III & Surgery & NA \\
\hline Asioli et al. [28] & 58 & 12 & NA & । & Surgery & NA \\
\hline Brennan et al. [30] & 74 & 22 & Parasagittal & $\|$ & Surgery & NA \\
\hline Kanzaki et al. [32] & 67 & 15 & NA & $\|$ & Surgery & NA \\
\hline Lambertz et al. [35] & 65 & 12 & Right frontal & $\|$ & & \\
\hline Tao et al. [39] & 51 & 1 & Right lateral ventricle & III & Surgery & NA \\
\hline Kansaki [32] & 67 & 15 & NA & $\|$ & Surgery & Alive \\
\hline Current case & 34 & Concurrent & Left parafalcine & । & Surgery & Alive \\
\hline
\end{tabular}

NA not available

unclear, but an increase in the expression of aquaporin (a water channel protein) during pregnancy and a positive effect of progesterone on vascular dilatation have been suggested [10]. It seems that, during pregnancy, due to hemodynamic changes, a preexisting meningioma may present with the clinical symptoms of elevated intracranial pressure, including headache, nausea, and vomiting. After pregnancy, shrinkage of the tumoral tissue may occur and the mass size may decrease on its own.

Although meningiomas are more common among females, metastasis has not been reported to be more common in this population. For instance, multiple pulmonary metastases from preexisting intracranial meningiomas are rare in females. To the best of our knowledge, 33 such cases have been reported in the literature (Table 1) $[1,2,7,13-41]$. The median age of the patients was 50 years (age range 26-91 years). In addition, the interval between the detection of the primary meningioma and the detection of lung metastases ranged from 9 to 19 years. In two cases, the lung mass was found concurrently with the primary brain tumor. Generally, lung metastases rarely cause symptoms such as cough and hemoptysis. In the present case, bilateral pulmonary nodules were found incidentally and the patient had no respiratory symptoms. The exact mechanism of multiple lung metastases from an intracranial tumor is not clear yet. Higher histological grades (II/III), venous sinus invasion, prior surgery for resection of the primary tumor, and tumor recurrence have been reported as the predictive factors for multiple lung metastases. Dissemination of tumor cells by hematogenous and lymphatic vessels or by cerebrospinal fluid (CSF) seeding have also been suggested as the underlying mechanisms of metastasis [42]. Tumor invasion to dural venous sinuses and cranial veins facilitate the hematogenous spread of tumoral cells to the pulmonary circulation [42]. The present case had a large mass with the invasion of the superior sagittal sinus and extension through the calvarium and scalp. Genetic abnormalities such as loss of heterozygosity at $9 \mathrm{p}, 1 \mathrm{p}$, and $22 q$ have also been considered the predictors of lung metastases [1].

Surgical resection is the current standard of care for primary low-grade meningiomas. For high-grade lesions, surgical resection is combined with adjuvant radiotherapy to prevent local recurrence. Thoracotomy to surgically excise the lung mass is the treatment of choice for metastatic lung masses. Due to the rarity of metastatic meningiomas, few clinical trials have been performed and no standard treatment is available. Previous studies assessed the efficacy of hydroxyurea, external beam radiation, and sunitinib in treatment of high-grade metastatic cases $[43,44]$.

\section{Conclusion}

In patients with intracranial meningiomas accompanied by venous sinus invasion and extension through the calvarium, metastasis must be considered and thorough paraclinical investigations are suggested. From a practical point of view, these seemingly benign lesions may not be as they appear, which emphasizes the importance of follow-up for such lesions beyond the scope of neurosurgery.

\footnotetext{
Acknowledgements

The authors would like to thank Ms. A. Keivanshekouh at the Research Consultation Center (RCC) of Shiraz University of Medical Sciences for improving the use of English in the manuscript.

\section{Authors' contributions}

NA drafted the article. AA and SP collected the data and participated in drafting the article. PM, AS, MV, and SHY performed the surgical operation, were in charge of the patient's status, obtained consent, collected the clinical data, and helped draft the manuscript. MHA performed the pathological
} 
examination and revised the article. PM and AS equally participated in the management of the case and have been considered as co-first authors. All authors read and approved the final manuscript.

\section{Funding}

None declared.

\section{Availability of data and materials}

No additional datasets were used for the creation of this manuscript. All information is available from the standard documentation in the patient's electronic medical record.

\section{Declarations}

\section{Ethics approval and consent to participate}

This study was approved by the Ethics Committee of Namazi Hospital. In addition, written informed consent was obtained from the patient.

\section{Consent for publication}

Written informed consent was obtained from the patient for publication of this case report and the accompanying images. A copy of the written consent is available for review by the Editor-in-Chief of the journal.

\section{Competing interests}

The authors declare that they have no competing interests.

\section{Author details}

${ }^{1}$ Thoracic and Vascular Surgery Research Center, Shiraz University of Medical Sciences, Shiraz, Iran. ${ }^{2}$ Department of Neurosurgery, Shiraz University of Medical Sciences, Shiraz, Iran. ${ }^{3}$ Student Research Committee, Shiraz University of Medical Sciences, Shiraz, Iran. ${ }^{4}$ Department of Pathology, Shiraz University of Medical Sciences, Shiraz, Iran. ${ }^{5}$ Transplant Research Center, Shiraz University of Medical Sciences, Shiraz, Iran. ${ }^{6}$ General Surgery Resident, Shiraz University of Medical Sciences, Shiraz, Iran. ${ }^{7}$ Neurosurgery Resident, Shiraz University of Medical Sciences, Shiraz, Iran.

Received: 1 June 2021 Accepted: 2 September 2021

Published online: 14 October 2021

\section{References}

1. Vakil H, Tran L, Lewis GD, Cykowski MD, Butler EB, Teh BS. Biopsy proven metastatic meningioma: a case report and review of the literature. Rep Pract Oncol Radiother. 2019;24(6):528-32.

2. Wang M, Zhan R, Zhang C, Zhou Y. Multiple pulmonary metastases in recurrent intracranial meningioma: case report and literature review. J Int Med Res. 2016;44(3):742-52.

3. He L, Yu S, Wang L. Rapid recurrence and malignant transformation of a benign meningioma after pregnancy: a case report. Br J Neurosurg. 2020;1:1-3.

4. Yekeler E, Dursun M, Yilmazbayhan D, Tunaci A. Multiple pulmonary metastases from intracranial meningioma: MR imaging findings (case report). Diagn Interv Radiol. 2005;11(1):28-30.

5. Kessler RA, Garzon-Muvdi T, Yang W, Weingart J, Olivi A, Huang J, et al. Metastatic atypical and anaplastic meningioma: a case series and review of the literature. World Neurosurg. 2017:101:47-56.

6. Pettersson-Segerlind J, Mathiesen T, Elmi-Terander A, Edström E, Talbäck $M$, Feychting $M$, et al. The risk of developing a meningioma during and after pregnancy. Sci Rep. 2021;11(1):9153.

7. Erman T, Hanta I, Haciyakupoğlu S, Zorludemir S, Zeren H, Göçer Al. Huge bilateral pulmonary and pleural metastasis from intracranial meningioma: a case report and review of the literature. J Neurooncol. 2005;74(2):179-81.

8. Hortobágyi T, Bencze J, Murnyák B, Kouhsari MC, Bognár L, Marko-Varga G. Pathophysiology of meningioma growth in pregnancy. Open Med (Wars). 2017;12:195-200.

9. Laviv $Y$, Ohla $V$, Kasper EM. Unique features of pregnancy-related meningiomas: lessons learned from 148 reported cases and theoretical implications of a prolactin modulated pathogenesis. Neurosurg Rev. 2018;41(1):95-108.

10. Lusis EA, Scheithauer BW, Yachnis AT, Fischer BR, Chicoine MR, Paulus W et al. Meningiomas in pregnancy: a clinicopathologic study of 17 cases. Neurosurgery. 2012;71(5):951-61.

11. Laviv Y, Ohla V, Kasper EM. Unique features of pregnancy-related meningiomas: lessons learned from 148 reported cases and theoretical implications of a prolactin modulated pathogenesis. Neurosurg Rev. 2018:41(1):95-108.

12. Telugu RB, Chowhan AK, Rukmangadha N, Patnayak R, Phaneendra BV, Mowliswara Prasad BC, et al. Estrogen and progesterone receptor in meningiomas: an immunohistochemical analysis. J Cancer Res Ther. 2020;16(6):1482-7.

13. Aumann JL, van den Bosch JM, Elbers JR, Wagenaar SJ. Metastatic meningioma of the lung. Thorax. 1986;41(6):487-8.

14. LeMay DR, Bucci MN, Farhat SM. Malignant transformation of recurrent meningioma with pulmonary metastases. Surg Neurol. 1989;31(5):365-8.

15. Hishima T, Fukayama M, Funata N, Mochizuki M, Hayashi Y, Koike M, et al Intracranial meningioma masquerading as a primary pleuropulmonary tumor. Pathol Int. 1995:45(8):617-21.

16. Murrah CP, Ferguson ER, Jennelle RL, Guthrie BL, Holman WL. Resection of multiple pulmonary metastases from a recurrent intracranial meningioma. Ann Thorac Surg. 1996;61(6):1823-4.

17. Adlakha A, Rao K, Adlakha H, Perry A, Crotty TB, Scheithauer BW, et al. Meningioma metastatic to the lung. Mayo Clin Proc. 1999;74(11):1129-33.

18. Figueroa BE, Quint DJ, McKeever PE, Chandler WF. Extracranial metastatic meningioma. Br J Radiol. 1999;72(857):513-6.

19. Travitzky M, Libson E, Nemirovsky I, Hadas I, Gabizon A. Doxil-induced regression of pleuro-pulmonary metastases in a patient with malignant meningioma. Anticancer Drugs. 2003;14(3):247-50.

20. Psaras T, Pantazis G, Steger $V$, Meyermann R, Honegger J, Beschorner R. Benign meningioma developing late lung metastases: case report and review of the literature. Clin Neuropathol. 2009;28(6):453-9.

21. Alexandru D, Glantz MJ, Kim L, Chamberlain MC, Bota DA. Pulmonary metastases in patients with recurrent, treatment-resistant meningioma: prognosis and identification by ${ }^{111}$ Indium-octreotide imaging. Cancer. 2011;117(19):4506-11.

22. Sabet A, Ahmadzadehfar H, Herrlinger U, Wilinek W, Biersack HJ, Ezziddin S. Successful radiopeptide targeting of metastatic anaplastic meningioma: case report. Radiat Oncol. 2011;6:94.

23. Nakayama $Y$, Horio H, Horiguchi S, Hato T. Pulmonary and pleural metastases from benign meningeal meningioma: a case report. Ann Thorac Cardiovasc Surg. 2014;20(5):410-3.

24. Ocque R, Khalbuss WE, Monaco SE, Michelow PM, Pantanowitz L. Cytopathology of extracranial ectopic and metastatic meningiomas. Acta Cytol. 2014:58(1):1-8.

25. Frydrychowicz C, Holland H, Hantmann H, Gradistanac T, Hoffmann KT, Mueller W, et al. Two cases of atypical meningioma with pulmonary metastases: a comparative cytogenetic analysis of chromosomes $1 \mathrm{p}$ and 22 and a review of the literature. Neuropathology. 2015;35(2):175-83.

26. Dalle Ore CL, Magill ST, Yen AJ, Shahin MN, Lee DS, Lucas CG, et al. Meningioma metastases: incidence and proposed screening paradigm. J Neurosurg. 2019;132(5):1447-55.

27. Sathirareuangchai S, Kakazu K, Tauchi-Nishi P, Morris P, Sae-Ow W. Low grade intracranial meningioma presenting with pulmonary metastasis: case report and literature review. Pathol Res Pract. 2019;215(7):152390.

28. Asioli S, Senetta R, Maldi E, D’Ambrosio E, Satolli MA, Bussolati G, et al. "Benign" metastatic meningioma: clinico-pathological analysis of one case metastasising to the lung and overview on the concepts of either primitive or metastatic meningiomas of the lung. Virchows Arch. 2007;450(5):591-4.

29. Baisden BL, Hamper UM, Ali SZ. Metastatic meningioma in fine-needle aspiration (FNA) of the lung: cytomorphologic finding. Diagn Cytopathol. 1999;20(5):291-4.

30. Brennan C, O'Connor OJ, O'Regan KN, Keohane C, Dineen J, Hinchion J, et al. Metastatic meningioma: positron emission tomography CT imaging findings. Br J Radiol. 2010;83(996):e259-62.

31. Fabi A, Nuzzo C, Vidiri A, Ciccarese M, Felici A, Cattani F, et al. Bone and lung metastases from intracranial meningioma. Anticancer Res. 2006;26(5b):3835-7. 
32. Kanzaki R, Higashiyama M, Fujiwara A, Tokunaga T, Maeda J, Okami J, et al. Surgical resection of pulmonary metastases from meningioma: report of a case. Surg Today. 2011;41(7):995-8.

33. Kodama K, Doi O, Higashiyama M, Horai T, Tateishi R, Nakagawa H. Primary and metastatic pulmonary meningioma. Cancer. 1991;67(5):1412-7.

34. Kovoor JM, Jayakumar PN, Srikanth SG, Indira B, Devi MG. Solitary pulmonary metastasis from intracranial meningiothelial meningioma. Australas Radiol. 2002;46(1):65-8.

35. Lambertz N, Koehler J, Schulte DM, Kuehl H, Wohlschlaeger J, Hense J, et al. Multivisceral systemic metastases from an intracranial anaplastic meningioma: a case report and review of literature. Clin Neurol Neurosurg. 2011;113(7):592-5

36. Pramesh CS, Saklani AP, Pantvaidya GH, Heroor AA, Naresh KN, Sharma $\mathrm{S}$, et al. Benign metastasizing meningioma. Jpn J Clin Oncol. 2003;33(2):86-8.

37. Shin MS, Holman WL, Herrera GA, Ho KJ. Extensive pulmonary metastasis of an intracranial meningioma with repeated recurrence: radiographic and pathologic features. South Med J. 1996;89(3):313-8.

38. Som PM, Sacher M, Strenger SW, Biller HF, Malis LI. "Benign" metastasizing meningiomas. AJNR Am J Neuroradiol. 1987;8(1):127-30.

39. Tao CY, Wang JJ, Li H, You C. Malignant intraventricular meningioma with craniospinal dissemination and concurrent pulmonary metastasis. World J Surg Oncol. 2014;12:238.
40. Tao LC. Pulmonary metastases from intracranial meningioma diagnosed by aspiration biopsy cytology. Acta Cytol. 1991;35(5):524-8.

41. Tworek JA, Mikhail AA, Blaivas M. Meningioma: local recurrence and pulmonary metastasis diagnosed by fine needle aspiration. Acta Cytol. 1997:41(3):946-7.

42. Lee GC, Choi SW, Kim SH, Kwon HJ. Multiple extracranial metastases of atypical meningiomas. J Korean Neurosurg Soc. 2009;45(2):107-11.

43. Kim J, Kim KH, Kim YZ. The clinical outcome of hydroxyurea chemotherapy after incomplete resection of atypical meningiomas. Brain Tumor Res Treat. 2017;5(2):77-86.

44. Kaley TJ, Wen P, Schiff D, Ligon K, Haidar S, Karimi S, et al. Phase II trial of sunitinib for recurrent and progressive atypical and anaplastic meningioma. Neuro Oncol. 2015;17(1):116-21.

\section{Publisher's Note}

Springer Nature remains neutral with regard to jurisdictional claims in published maps and institutional affiliations.
Ready to submit your research? Choose BMC and benefit from:

- fast, convenient online submission

- thorough peer review by experienced researchers in your field

- rapid publication on acceptance

- support for research data, including large and complex data types

- gold Open Access which fosters wider collaboration and increased citations

- maximum visibility for your research: over $100 \mathrm{M}$ website views per year

At BMC, research is always in progress.

Learn more biomedcentral.com/submissions 